\title{
Soft Tissue Giant Cell Tumor of Low Malignant Potential of the Neck: A Case Report and Review of the Literature
}

\author{
Boyunun Düşük Malign Potansiyelli Dev Hücreli Tümörü: \\ Olgu Sunumu ve Literatürün Gözden Geçirilmesi
}

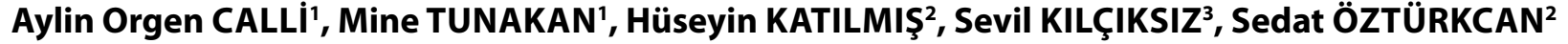 \\ Department of 'Pathology, ${ }^{2}$ Otorhinolaryngology, ${ }^{3}$ Radiation Oncology, Izmir Katip Celebi University Atatürk Training and Research Hospital, IZMIR, TURKEY
}

\section{ABSTRACT}

Giant cell tumor of soft parts is a rare tumor that is clinically and histologically similar to giant cell tumor of the bone. We present a 53-year-old female with a giant cell tumor of low malignant potential arising from the neck. The clinicopathological features and the importance of immunohistochemistry in the differential diagnosis with other giant cell rich tumors was discussed.

Key Words: Soft tissue neoplasms, Giant cell tumors, Head and neck neoplasms

\section{INTRODUCTION}

Giant cell tumor of soft parts (GCTSP) is an extremely rare soft tissue tumor that resembles its counterpart in bone. It is considered a soft tissue counterpart of giant cell tumor of the bone (1-3). The tumor is composed of an admixture of osteoclast-like multinucleated giant cells and mononuclear stromal cells $(3,4)$. The lesion was first described in 1972 by Salm and Sissons and Guccion and Enzinger $(3,4)$. Salm and Sissons reported a series of 10 benign GCTSP which were analogous to giant cell tumor of bone (3). However, in a series of thirty two cases, Guccian and Enzinger noticed that majority of the tumors exhibited agressive clinical behavior. Their study was the first to recognize malignant behavior in GCTSP (4). This pathologic entity was later labeled "malignant fibrous histiocytoma, giant cell type" based on the fact that these tumors were linked histogenetically to malignant fibrous histiocytoma (2). Later, Folpe et al. reported thirty-one additional cases with the same histopathologic features but yet lacking marked cytologic atypia and reclassified it as "giant cell tumor of low malignant potential" (5). In their article, Folpe et al emphasize that some tumors may show mitotic activity and vascular invasion. Two additional major series of patients

(Turk Patoloji Derg 2014, 30:73-77)

Received : 30.03.2011 Accepted : 09.05.2011

\section{ÖZ}

Yumuşak dokunun dev hücreli tümörü, kemiğin dev hücreli tümörüne klinik ve histolojik olarak benzeyen, nadir görülen bir tümördür. Burada, 53 yaşındaki kadın hastada boyunundan köken alan düşük malign potansiyelli dev hücreli tümör olgusu sunuldu. Klinikopatolojik özellikleri ve diğer dev hücreden zengin tümörlerden ayırıcı tanısında immünohistokimyanın önemi tartışıldı.

Anahtar Sözcükler: Yumuşak doku tümörleri, Dev hücreli tümörler, Baş boyun tümörleri with GCTS have subsequently been reported (6,7). Recently, tumors with similar histopathologic features have been described in numerous different anatomic sites including extremities, trunk, breast, and skin (5-10). Although many uncommon locations have been reported, the disease is rarely present in the head and neck (7,11-16).

Here, we report a case of rare GCTSP arising in the neck and we describe the clinicopathologic features and discuss the importance of immunohistochemistry in the differential diagnosis with other giant cell rich tumors.

\section{CASE REPORT}

A 53-year-old woman was admitted to an outside hospital with the complaint of a slowly enlarging, non-tender left neck mass that had been present for approximately one year. Ultrasonography of the neck revealed a $3.3 \times 2.3 \mathrm{~cm}$, lobulated contoured, solitary mass containing hypoechoic areas (Figure 1). A computed tomography (CT) scan demonstrated a $4 \times 3 \mathrm{~cm}$ heterogenous, soft tissue mass with enhancing margins adjacent to the sternocleidomastoid muscle. To make a definite diagnosis, an incisional biopsy was performed. The histopathological diagnosis of the incisional biopsy was benign fibrohistiocytic

Correspondence: Aylin Orgen CALLİ

İzmir Atatürk Eğitim ve Araştırma Hastanesi, Patoloji Bölümü,

IZMMIR, TURKEY

E-mail: calliaylin@gmail.com Phone: +90 5053521022 


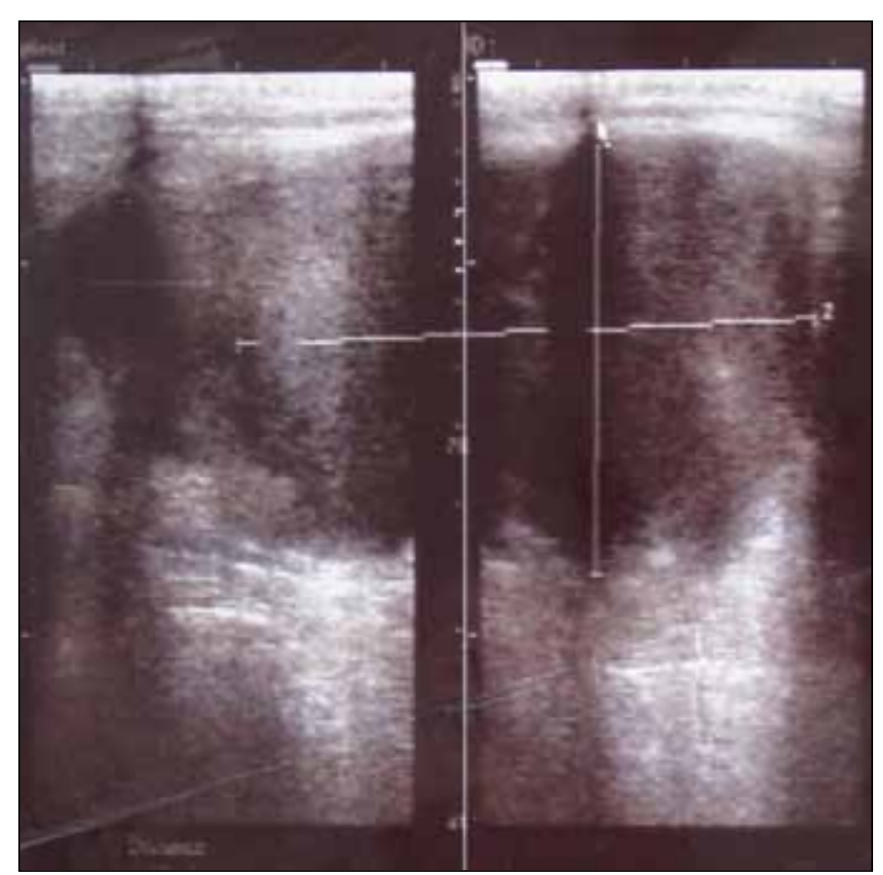

Figure 1: Ultrasonography of the head and neck shows solid mass.

tumor. The patient was later referred to our hospital for further evaluation. After the initial diagnosis, the patient underwent surgical excision of the tumor. Clinical examination showed a mobile, non-tender, solitary $5 \times 4$ $\mathrm{cm}$ mass in the left posterior cervical area. A complete surgical excision with a wide margin of the mass along with a cuff of uninvolved adipose tissue was performed. The excision specimen consisted of a non-circumscribed mass with intact overlying skin, measuring $6 \mathrm{~cm}$ in its greatest dimension. Macroscopic examination revealed a solitary, grayish mass. On histologic examination, the tumor showed involvement of the soft tissue by coarse multiple tumor nodules (Figure $2 \mathrm{~A}$ ). The individual tumor nodules were composed of an admixture of osteoclast-like multinucleated giant cells and bland mononuclear cells with eosinophilic cytoplasm, round to oval nuclei, fine chromatin (Figure 2B). Osteoclast-type giant cells with abundant eosinophilic to amphophilic cytoplasm and multiple vesicular nuclei with chromatin clumping were observed. In focal areas, oval plump mononuclear cells exhibited mild nuclear atypia (Figure 2C). Clusters of lymphocytes, plasma cells, and many macrophages containing hemosiderin were also noted. Osteoid and cartilaginous matrix were not seen. Occasionally areas of haemorrhage were observed. Striking nuclear atypia, necrosis and atypical mitotic figures were not present in this lesion. All resection margins were clear of malignancy.
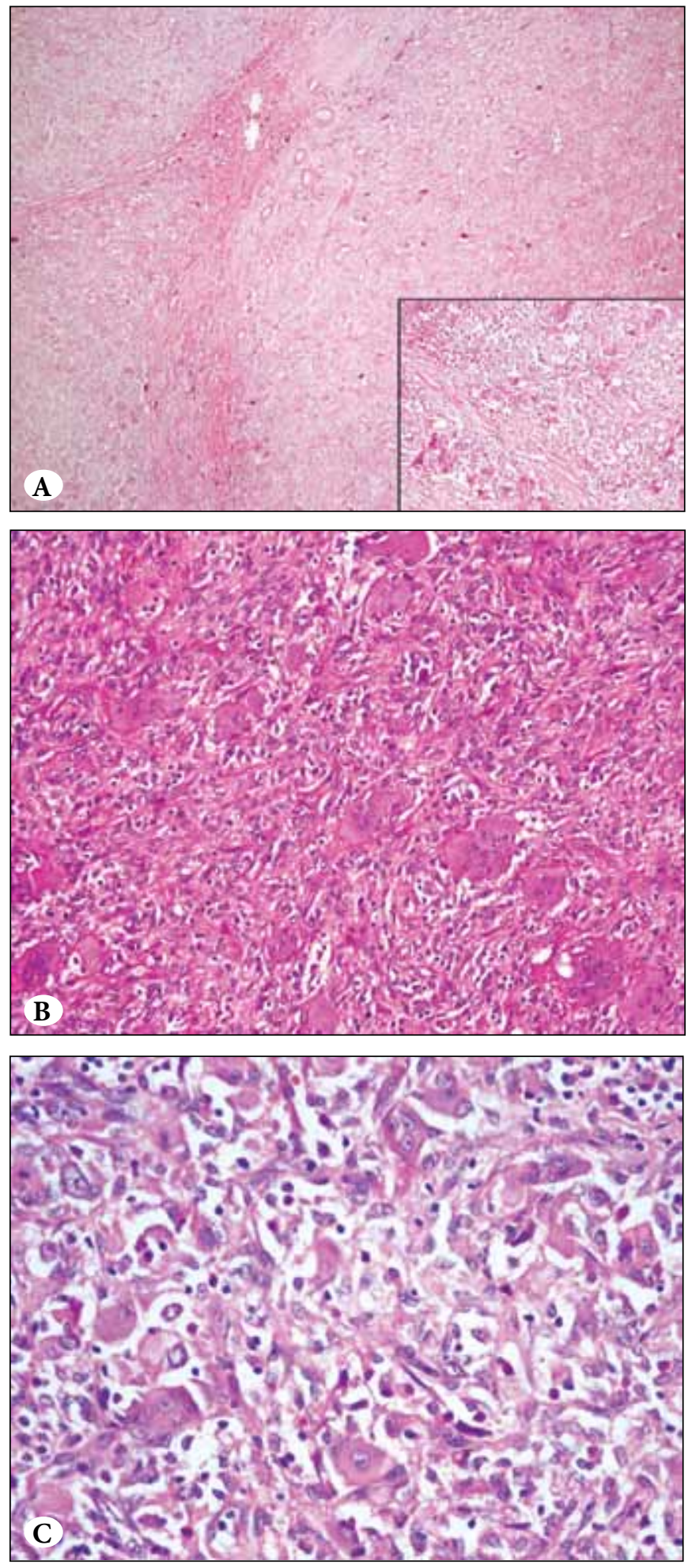

Figure 2: Histological features of GCTSP. (A) Tumor was coarse nodular in shape in the surrounding soft tissue (H\&E, x100), (B) Osteoclast-like multinucleated giant cell are numerous and mixed with bland-appearing spindle cells (H\&E, x200), (C) The mononuclear cells with round to ovoid nuclei with mild atypia, interspersed with multinucleated giant cells ( $\mathrm{H} \& \mathrm{E}, \mathrm{x} 400)$. 
Immunostainings for CD68, S-100 protein, pancytokeratin, [alpha]-1-antitrypsin (AAT), lysozyme, and vimentin were performed using a sensitive biotin-streptavidin immunoperoxidase technique on $5 \mu$ paraffin sections. CD68 immunoreactivity was strong and diffuse in the multinucleated giant cells and focal in the mononuclear cells (Figure 3). Mononuclear and multinucleated tumor cells were also positive for vimentin and alpha-1-antityripsin. Immunohistochemically, lysozyme showed scattered positive spindle cells among negative giant cells. However, both giant cells and spindle cells were negative for S-100, cytokeratin (AE1), and smooth muscle actin. Based on the histopathological and immunohistochemical findings, the final diagnosis of the present case was soft tissue giant cell tumour of low malignant potential.

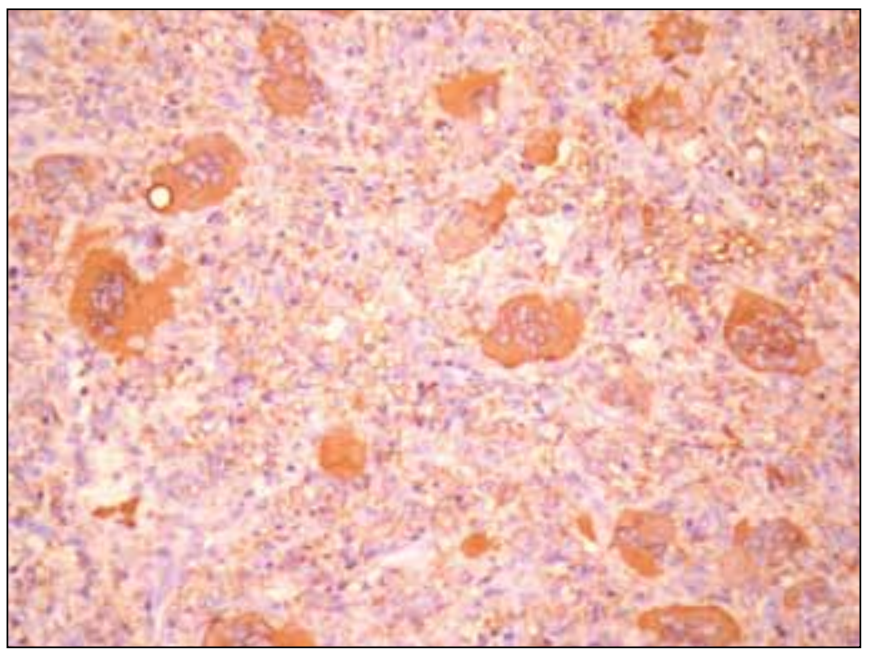

Figure 3: Immunohistochemistry demonstrates positive staining of many of them mononuclear and multinuclear cells with antibodies to CD68 (Peroxidase stain; x200).

\section{DISCUSSION}

Although giant cell tumors of soft parts are very uncommon neoplasms, they have been described in numerous anotomic sites including extremities, trunk, superficial and deep fascia, tendon sheath, and skeletal muscle (2,5-10). Head and neck tumors containing multinucleated giant cells are uncommon lesions in contrast to giant cell tumors that commonly arise in the bone. Most of the time, GCTSP arises in the extremities, thigh and trunk, but very rarely it arises in the head and neck localization (7,11-16). Recently, Pepper et al. reported case of a soft tissue giant cell tumour of low malignant potential that occurred in the left masseter muscle. To the best of our knowledge, very few cases in the neck have been reported in the medical literature. Trabelsi et al. presented a case of a 28 -year-old man who complained of a painless mass in the left posterior neck (17). Likewise, we here describe a case of a GCTSP in the neck.

Giant cell tumors of soft parts have now been reclassified as GCT-ST (i.e., giant cell tumor of low malignant potential) and undifferentiated pleomorphic sarcoma with giant cells (i.e., giant cell malignant fibrous histiocytoma or malignant giant cell tumor of soft parts) in the current (2002) WHO Classification of Tumors of Soft Tissue and Bone (18).

The main differential diagnosis includes giant cell tumor tendon sheath (GCTTS), giant cell reparative granuloma (central giant cell tumors), and giant cell rich malignant fibrous histiocytoma.

GCTTS is an extraarticular counterpart of pigmented villonodular synovitis, that is composed largely of mononuclear histiocytoid cells with scattered osteoclast and Touton type of giant cells, with xanthoma cells. It is different from GCTSP because of its usual localization near joint spaces or bursae, a generally uninodular rather than multinodular growth pattern, and paucity of the giant cells. Metaplastic bone production is not commonly seen in GCTTS. Both tumors are composed of large mononuclear histiocytoid cells and osteoclast type giant cells, but Touton type giant cells are also present in GCTTS. The ratio of giant cells to mononuclear cells is reversed in these two lesions. Unlike GCTTS, large amounts of dense fibrous tissue are absent or scarce in GCTSP $(1,2,19,20)$.

Giant cell reparative granuloma or peripheral giant cell granuloma (PGCG) arises exclusively from the periodontal ligament enclosing the root of a tooth. This unique origin means that such a lesion can only be found within or upon the gingiva or alveolar ridge. Apart from the rather significant difference in location, giant cells in PGCG tend to have fewer nuclei and irregular shapes. They have propensity for clustering around areas of necrosis and haemorrhage, while those in GCTSP are more evenly distributed. There is an increased incidence of osteoid, haemorrhage, and hemosiderin in PGCG compared with GCTSP $(1,2,20,21)$.

GCTSP should be considered different from giant cell rich malignant fibrous histiocytoma (MFH) because the latter is a more aggressive, high grade malignant tumor. Giant cell rich MFH is a multinodular, storiform-pleomorphic MFH with marked cytologic atypia, atypical mitoses, and benign osteoclast-like giant cells. However, GCTSP lack the numerous atypical mitoses and coagulative tumor cell necrosis typical of giant cell rich MFH. The current choice of treatment is to combine aggressive surgical resection and postoperative radiotherapy for these malignant tumors 
$(1,2,20)$. Therefore, GCTSP should be separated from giant cell rich MFH, because of their quite different biologic behavior, and far better prognosis.

The differential diagnosis also includes plexiform fibrohistiocytic tumor (PFT). Dermal/subcutaneous location, and identification of bimodal population of cells in these tumors often allows for its distinction. Unlike GCTSP, which shows coarser multinodular pattern, PFT reveals plexiform growth pattern with minute nodules or short facicles of fibroblasts at the dermal subcutaneous interface. In addition, PFT tends to arise in younger patients in a truncal location $(1,2,20)$.

Intravascular fasciitis (IF) may resemble GCTSP because of considerable number of multinucleated giant cells. Typical areas of nodular faciitis characterized by somewhat randomly arrayed bland myofibroblastic cells that are commonly associated with with microcystic change should be searched for the diagnosis of IF. IF involves small or medium-sized veins or arteries in contrast to GCTSP wherein the bulk of the tumor is situated in the dermis $(1,2,20)$.

Although histologic characteristics of giant cell tumor suggest a mesenchymal origin, the histogenesis is still unknown. The giant cells resemble osteoclasts both microscopically and ultrastructurally. They also have a certain content of hydrolytic enzymes such as acid phosphatase. Recently, some studies have confirmed the osteoclastic nature of giant cells in giant-cell-rich MFH and have shown that osteoclasts are also present in the GCTSP of low-grade malignant potential (22).

The treatment of GCTSP remains controversial because of the small number of reported cases. Radical surgery has been widely accepted as a mode of treatment for GCTSP. However, because of the possibility of local recurrence, clinical follow up with or without postoperative radiotherapy is advised after excision. Although some authors advocate adjuvant radiotherapy as a treatment of GCTSP, many aspects of this mode of treatment have not been clarified (15). After a multidisciplinary discussion, postoperative radiotherapy was proposed. Our patient was given postoperative radiotherapy to the neck. The affected side of the ipsilateral neck was treated with opposed tangential fields. She received 5000 cGy in 25 fractions delivered over a period 5 weeks.

In patients with clinical follow-up that ranges from 34 to 45 months, GCTSP was associated with a local recurrence rate of $12 \%$, and very rare metastasis and death. No clinicopathologic factors are currently predictive of metastatic behaviour associated with GCTSP $(1,6,7)$. Two years after surgical and radiotherapy treatment, our case was alive and showed no evidence of recurrence and or metastasis.

In conclusion, GCTSP should be kept in mind in the differential diagnosis of other osteoclast-like giant cell-rich tumors of the neck.

\section{REFERENCES}

1. Fletcher CDM, Unni KK, Mertens F. Pathology and genetics of tumors of soft tissue and bone. WHO Classification of Tumors. Lyon: IARC Pres; 2002. 310-2.

2. Weiss SW, Goldblum JR (Eds). Enzinger and Weiss's soft tissue tumours. 5th ed. Philadelphia: Elsevier; 2008. 398-401.

3. Salm R, Sissons HA. Giant cell tumors of soft tissues. J Pathol. 1972;107:27-39.

4. Guccion JG, Enzinger FM. Malignant giant cell tumor of soft parts. An analysis of 32 cases. Cancer. 1972;29:1518-29.

5. Folpe AL, Morris RJ, Weiss SW. Soft tissue giant cell tumor of low malignant potential: A proposal for the reclassification of malignant giant cell tumor of soft parts. Mod Pathol. 1999;12: 894-902.

6. O'Connell JX, Wehrli BM, Nielsen GP, Rosenberg AE. Giant cell tumors of soft tissue: A clinicopathologic study of 18 benign and malignant tumors. Am J Surg Pathol. 2000;24:386-95.

7. Oliveira AM, Dei Tos AP, Fletcher CD, Nascimento AG. Primary giant cell tumor of soft tissues: A study of 22 cases. Am J Surg Pathol. 2000;24:248-56.

8. Rodriguez-Peralto JL, Lopez-Barea F, Fernandez-Delgado J. Primary giant cell tumor of soft tissues similar to bone giant cell tumor: A case report and literature review. Pathol Int. 2001;51: 60-3.

9. May SA, Deavers MT, Resetkova E, Johnson D, Albarracin CT. Giant cell tumor of soft tissue arising in breast. Ann Diagn Pathol. 2007;11:345-9.

10. Boneschi V, Parafioriti A, Armiraglio E, Gaiani F, Brambilla L. Primary giant cell tumor of soft tissue of the groin - a case of 46 years duration. J Cutan Pathol. 2009;36(Suppl 1):20-4.

11. Tuluc M, Zhang X, Inniss S. Giant cell tumor of the nasal cavity: Case report. Eur Arch Otorhinolaryngol. 2007;264:205-8.

12. Ryś J, Kruczak A, Marczyk E, Skotnicki P, Moskal J, Ambicka A, Harazin-Lechowska A, Wasilewska A, Vogelgesang M, Dyczek S. Primary soft tissue giant cell tumour of the neck. Cytological and histological characteristics of the tumour and differential diagnosis. Pol J Pathol. 2009;60:98-104, quiz 105.

13. Pepper T, Falla L, Brennan PA. Soft tissue giant cell tumour of low malignant potential arising in the masseter-a rare entity in the head and neck. Br J Oral Maxillofac Surg. 2010;48:149-51.

14. Wieneke JA, Gannon FH, Heffner DK, Thompson LD. Giant cell tumor of the larynx: A clinicopathologic series of eight cases and a review of the literature. Mod Pathol. 2001;14:1209-15.

15. Werner JA, Harms D, Beigel A. Giant cell tumor of the larynx: Case report and review of the literature. Head Neck. 1997;19: 153-7. 
16. Hoang MP, Rogers BB, Albores-Saavedra J. Giant cell tumor of the skin: A morphologic and immunohistochemical study of five cases. Ann Diagn Pathol. 2002;6:288-93.

17. Trabelsi A, Hammedi F, Slama A, Abdelkarim SB, Beïzig N, Khochtali H, Taher YM, Korbi S. Giant cell tumor of soft tissue of neck: A case report. North Am J Med Sci. 2009;1:319-20.

18. Nascimento AG: Giant cell tumor of soft tissue. In: Fletcher CDM, Unni KK, Mertens F, editors. World Health Organization Classification of Tumours. Pathology and genetics of tumours of soft tissue and bone. Lyon: IARC Press; 2002. 118-9.

19. Beal M, Mayerson J, Wakely PE Jr. Fine-needle aspiration cytology of giant cell tumor of soft tissue (soft tissue giant cell tumor of low malignant potential). Ann Diagn Pathol. 2003;7:365-9.
20. Guillou L, Folpe AL. Fibroblastic and fibrohistiocytic tumors of soft tissue. In: Folpe AL, Inwards CY, editors. Bone and soft tissue pathology - A volume in the Foundations in Diagnostic Pathology Series. 1st ed. Philadelphia: Elsevier Inc; 2010.

21. Katsikeris N, Kakarantza-Angelopoulou E, Angelopoulos AP. Peripheral giant cell granuloma: Clinicopathologic study of 224 new cases and review of 959 reported cases. Int J Oral Maxillofac Surg. 1988;17: 94-9.

22. Lau YS, Sabokbar A, Gibbons CL, Giele H, Athanasou N. Phenotypic and molecular studies of giant-cell tumors of bone and soft tissue. Hum Pathol. 2005;36: 945-54. 